\title{
THE DAY-OF-THE-WEEK EFFECT: SOUTH AFRICAN STOCK MARKET INDICES
}

\author{
*Elda du Toit and John Henry Hall \\ Department of Financial Management, University of Pretoria \\ Rudra P. Pradhan \\ Vinod Gupta School of Management, Indian Institute of Technology Kharagpur
}

*Corresponding author: elda.dutoit@up.ac.za

\begin{abstract}
Purpose

The presence of a day-of-the-week effect has been investigated by many researchers over many years, using a variety of financial data and methods. However, differences in methodology between studies could have led to conflicting results. The present study expands on an existing study to observe whether an analysis of the same dataset with some added years, and using a different statistical technique provide the same results.
\end{abstract}

\section{Design/methodology/approach}

The study examines the presence of a day-of-the-week effect on the Johannesburg Stock Exchange indices for the period March 1995 to March 2016, using a GARCH model.

\section{Findings}

The findings show that, contrary to the original study, the day-of-the week effect is present in both volatility and return equations. The highest and lowest returns are observed on Monday and Friday respectively, while volatility is observed on all five days from Monday to Friday.

\section{Originality/value}

This study adds to the existing literature on day-of-the-week effect of Johannesburg Stock Exchange indices, where different patterns or, in some cases, no pattern have been noted. Few previous studies on the day-of-the-week effect observed the effect at micro-level for separate industries or made use of a GARCH model. The present study thus expands on the study of Mbululu and Chipeta (2012), by adding four additional observation years and using a different statistical technique, to observe differences that arise from a different time period and statistical 
technique. The results indicate that a day-of-the-week effect is mostly a function of the statistical technique applied.

Keywords: Day-of-the-week effect, Volatility, GARCH, JSE indices

JEL Classification: C22, G10, G12

\section{Introduction}

The efficiency of a market refers to the extent to which the decisions of all market participants cumulatively reflect the value of listed companies and their share price at any given time. This principle is known as the efficient market hypothesis $(\mathrm{EMH})$, which states that it is impossible for an investor to outclass the market, as the efficiency of the stock market causes existing share prices to always incorporate and reflect all relevant information.

When there is a pattern in the share price or the returns of a share, it provides evidence of market anomalies, since the market is supposed to follow a so-called 'random walk' according to the EMH. There are several market anomalies in existence; with some appearing once and then disappearing, while others are frequently observed. Market anomalies include, amongst others, the day-of-the-week effect (also known as the weekend effect, Monday effect, or intraday effect), the January effect, the turn-of-the-month effect, the weather effect, and the small firm effect. The day-of-the-week effect have been extensively investigated by researchers in various countries, including Alagidede (2008); Berument and Dogan (2012); Brusa and Liu (2004); Choudhary and Choudhary (2008); Chukwuogor (2007); Darrat et al. (2013); Dicle and Levendis (2014); Hsieh and Chen (2012); Jefferis and Smith (2005); Kalidas et al. (2013); Latif et al. (2011); Mbululu and Chipeta (2012); Ndako (2013); Plimsoll et al. (2013); Rowjee (2014b); Smirlock and Starks (1986); Ulussever et al. (2011).

The 'traditional' view of a day-of-the-week effect is that stocks tend to exhibit large returns on Fridays compared to Mondays, due to investor behaviour. Lakonishok and Maberly (1990) suggested the reason for this is that investors re-evaluate their portfolios on a Monday after bad 
news released over the weekend and thus mostly sell on a Monday. However, this finding has not been confirmed. Research to determine the existence of the day-of-the-week effect on the Johannesburg Stock Exchange (JSE) has resulted in inconsistent evidence (Bhana, 1985; Chukwuogor, 2007; Coutts and Sheikh, 2002; Kalidas et al., 2013; Mbululu and Chipeta, 2012; Plimsoll et al., 2013). Inconsistencies in the results could be attributable to the different sample groups, sample periods, and statistical techniques used by various researchers. Inconsistent results do, however, lead to uncertainty about the existence of any day-of-the-week effect on the JSE and how it can be applied in investment decisions. Knowing if a day-of-the-week effect exist and when it occur, is essential for investment decisions. Knowledge of when a particular share is expected to perform exceptionally well and when it is expected to underperform, provides investors with the opportunity to control their returns when they make buy or sell decisions.

Because of inconsistent results in research on the day-of-the-week effect, Mbululu and Chipeta (2012) suggested that the scope of these studies should be narrowed down and evaluated over the same sample period to effectively determine and compare the existence of the effect. The purpose of the present study is thus to also investigate the day-of-the-week effect on the different indices of the JSE for the period 4 July 1995 to 16 March 2016, but with a different statistical technique from what was used by Mbululu and Chipeta (2012). Few previous studies on the day-of-the-week effect observed the effect at micro-level for separate industries or made use of $\mathrm{ARCH}$ and GARCH models. The present study thus expands on the study of Mbululu and Chipeta (2012), by adding four additional observation years and using a different statistical technique, to observe differences that arise from a different time period as well as the statistical technique implemented. The results may render the results of a day-of-the-week study a function of the time period of the data and the statistical technique applied. It is important to establish the most appropriate statistical technique to use and the optimal time period so as to ensure that day-of-the-week effects are accurately predicted for the benefit of market participants and to ensure reliable results for future academic studies. This study contributes to the existing literature in providing a method that indicates the presence a day-of-the-week effect, which can then be applied to other studies. 
The rest of the paper is organised as follows: Section 2 presents the literature; Section 3 details the empirical model and data used in the study; Section 4 offers and discusses the empirical results; and Section 5 specifies conclusions and the consequent policy implications.

\section{Literature}

Stock markets offer a platform where shares can be valued efficiently. An efficient market is one that reports stock prices which fully reflect available information and maintain the return-risk relationship (Hamid et al., 2010; Latif et al., 2011; Malkiel, 2003). However, if there is any pattern in share price movements, it shows that the market is not efficient and that market anomalies can be exploited to the advantage of investors.

The efficient market hypothesis $(\mathrm{EMH})$ requires investors to hold rational expectations, which they adjust according to positive or negative information as it is made available. There are three forms of market efficiency, namely strong-form efficiency, where share prices reflect all market information; semi-strong efficiency, where share prices reflect all publicly available information promptly and in an unbiased manner; and weak-form efficiency, which displays an incapability for future prices to be predicted on the basis of past movements. It is rare that the market can reflect all available information and historical information lacks in its ability to predict the future. Therefore stock markets provide an opportunity for anomalies such as the day-of-the-week effect, where abnormal returns can be earned. The existence of calendar anomalies, like the day-of-the-week effect, disagree with both the EMH and the random walk theory by exhibiting seasonal patterns in share prices at certain times of the year (Rowjee, 2014b). Past literature on the efficiency of the JSE established that, due to calendar anomalies, it displays the character of a weak-form market (Mbululu and Chipeta, 2012; Plimsoll et al., 2013).

Earliest evidence of the day-of-the-week effect appeared in 1931 (Fields, 1931). At that time, investors on Wall Street sold off long accounts towards the weekend, which caused the share price to decline on Saturdays. Using the Dow-Jones daily average of industrials, Saturday's index was compared with the average of the Friday and Monday index values. Although little 
information was available on the day-of-the-week effect at that time, Fields (1931) was able to determine that the average closing share prices on Saturday were not lower than the average of Friday and Monday. However, since then, the results of subsequent studies on a day-of-theweek effect have been mainly inconclusive. One of the earliest studies on the presence of a day-of-the-week effect on the JSE was conducted by Bhana (1985). He found, upon investigation of shares traded between 1978 and 1983, that Monday trading sessions experienced the most adverse average returns, whilst Wednesday sessions produced the most positive returns. A study by Chang et al. (1993), who included South Africa in their sample, found evidence of a day-of-the-week effect only in France, Italy, the Netherlands, Spain and Sweden. But, the countries' results differ as to the specific day, as well as the week in the month that the effect is present. Their results indicated an insignificant effect in the US market.

Results were inconsistent in various other international studies. Contrary to Chang et al. (1993), Abraham and Ikenberry (1994) found a definite day-of-the-week effect in the US, which they investigated further to establish whether there is a fixed relationship between Monday and Friday returns. Steeley (2001) found that the day-of-the-week effect disappeared during the 1990s in the UK equity market. An explanation for this finding was at the time speculated to be a noticeable pattern in the arrival of market-wide news into the market, with a great deal of information released from Tuesday to Thursday and very little on Mondays and Fridays. Brusa and Liu (2004) found the traditional weekend effect to be present in the US market, but that it reversed between 1988 and 1998.

More recently, Mlambo and Biekpe (2006), Alagidede (2008), Mbululu and Chipeta (2012), Darrat et al. (2013) and Plimsoll et al. (2013) all confirm the presence of limited and spurious day-of-the week effects on the indices of different African stock markets. However, because results differ across industries, stock markets, and periods, no definitive conclusion about the presence of any such effects can be confirmed. Chukwuogor (2007); Coutts and Sheikh (2002) and Kalidas et al. (2013) concluded that no day-of-the-week anomaly exist on the JSE. 
Miller (1988) and Lakonishok and Maberly (1990) claim that individual investors create a day-ofthe-week effect. The first reason stems from the special costs incurred by individual investors when they examine their market portfolios. The second reason relates to the receipt of information from the broker fraternity. As it is costly for individual investors to obtain market information during trading hours when they are engaged in full-time employment, the weekend presents the perfect opportunity to gather important information about investments. This information, depending on its gravity, is then used on a Monday when stock markets reopen and thus affects the level of returns received for that day. In contrast, Brockman and Michayluk (1998) and Pettengill (2003) speculate that institutional investors are to blame for the day-ofthe-week effect. They contend that, because institutional investors trade portfolios instead of individual securities, they are the reason for negative returns on a Monday. Table 1 presents a summary of some of the available research on the day-of-the-week effect over a period of 32 years.

What is clear from the literature is that there still exists uncertainty about any fixed or definite presence of a day-of-the week effect in stock markets. In addition, where it is present, it is spurious and inconsistent. In terms of African studies alone, the day-of-the-week effect seems to be mostly non-existent. Effects could be observed in the Nigerian and South African stock markets, but the direction of the effect and the particular day was inconsistent. These differing results may be attributed to different statistical techniques implemented, since there seems to be some consistency in the results of past studies where the same statistical technique was applied.

There are significant differences in the data of the different day-of-the-week studies that have been performed in the past. Some studies were conducted on micro-level, looking at individual firms or indices, while others were conducted at macro-level, thus by looking at entire stock markets. The studies were also performed over various periods and in different countries, using different statistical techniques. The lack of consistency between the studies thus necessitates the need for research to the day-of-the-week-effect with a different focus to establish whether the phenomenon of a day-of-the-week effect exists and to pave the way for future research. 
Table 1: Summary of a selection of day-of-the-week studies

\begin{tabular}{|c|c|c|c|c|c|}
\hline Author(s) & Period & Country & Statistical technique & Data & Results \\
\hline $\begin{array}{l}\text { Abraham and } \\
\text { lkenberry (1994) }\end{array}$ & 1963 to 1991 & US & T-test & Stock exchange data & Monday effect \\
\hline $\begin{array}{l}\text { Aggarwal and Rivoli } \\
\text { (1989) }\end{array}$ & 1976 to 1988 & $\begin{array}{l}\text { Hong Kong, Singapore, } \\
\text { Malaysia and Philippines }\end{array}$ & Multiple regression & Industrial indices & Negative Monday effect \\
\hline $\begin{array}{l}\text { Akbalik and Ozkan } \\
(2017)\end{array}$ & 2009 to 2015 & $\begin{array}{l}\text { Brazil, Indonesia, Turkey and } \\
\text { South Africa }\end{array}$ & $\begin{array}{l}\text { Kruskal-Wallis } \\
\text { Wilcoxon rank sum }\end{array}$ & Basic indices & $\begin{array}{l}\text { No effect, except Indonesia with low } \\
\text { Monday and high Wednesday. South } \\
\text { Africa positive Monday, but } \\
\text { insignificant. }\end{array}$ \\
\hline Alagidede (2008) & Various to 2006 & $\begin{array}{l}\text { Egypt, Kenya, Morocco and } \\
\text { Tunisia, Zimbabwe, Nigeria } \\
\text { and South Africa }\end{array}$ & OLS, ARCH and GARCH & Stock exchange data & $\begin{array}{l}\text { No effect in Egypt, Kenya, Morocco } \\
\text { and Tunisia. Positive Friday effect in } \\
\text { Zimbabwe and Nigeria. Negative } \\
\text { Friday effect in South Africa. }\end{array}$ \\
\hline $\begin{array}{l}\text { Al-Loughani et al. } \\
\text { (2005) }\end{array}$ & $\begin{array}{l}1984 \text { to } 1990 \text { and } 1993 \text { to } \\
2000\end{array}$ & Kuwait & $\begin{array}{l}\text { T-test } \\
\text { Mann-Whitney test } \\
\text { Kruskal-Wallis test } \\
\end{array}$ & Stock exchange data & No holiday effect \\
\hline $\begin{array}{l}\text { Berument and Dogan } \\
(2012)\end{array}$ & 1952 to 2006 & US & $\mathrm{ARCH}$ and $\mathrm{EGARCH}$ & Stock exchange data & Negative Monday effect \\
\hline Bhana (1985) & 1978 to 1983 & South Africa & Multiple regression & $\begin{array}{l}\text { Stock exchange data } \\
\text { Industrial index } \\
\end{array}$ & Negative Monday effect \\
\hline $\begin{array}{l}\text { Brockman and } \\
\text { Michayluk (1998) }\end{array}$ & 1963 to 1993 & US & T-test & Stock exchange data & Monday effect \\
\hline Brusa and Liu (2004) & 1988 to 1998 & US & Multiple regression & Indices & Positive Monday effect \\
\hline Brusa et al. (2003) & 1963 to 1995 & US & OLS & Dow Jones Industrial Average & Positive Monday effect \\
\hline Brusa et al. (2003) & 1988 to 1995 & $\begin{array}{l}\text { Australia, Japan, Hong Kong, } \\
\text { France, UK, Chile, Brazil, } \\
\text { Argentina } \\
\end{array}$ & OLS & Stock exchange data & Negative Monday effect \\
\hline Chang et al. (1993) & 1985 to 1992 & \begin{tabular}{|l|}
23 countries on various \\
continents
\end{tabular} & OLS & FT-Actuaries World Indices & Various results across countries \\
\hline Chatterjee (2017) & 2002 to 2015 & US & GARCH & Biotechnology Index & $\begin{array}{l}\text { Negative Monday effect with positive } \\
\text { Wednesday, Thursday and Friday } \\
\text { effects. }\end{array}$ \\
\hline $\begin{array}{l}\text { Choudhary and } \\
\text { Choudhary (2008) }\end{array}$ & Various to 2008 & $\begin{array}{l}20 \text { countries on various } \\
\text { continents } \\
\end{array}$ & $\begin{array}{l}\text { ANOVA } \\
\text { Kruskal-Wallis }\end{array}$ & Stock exchange data & Various results across countries \\
\hline Chukwuogor (2007) & 1997 to 2004 & $\begin{array}{l}\text { Botswana, Ghana, Nigeria, } \\
\text { Egypt, South Africa }\end{array}$ & Kruskal-Wallis & Stock exchange data & $\begin{array}{l}\text { No day-of-the-week effect in any } \\
\text { country }\end{array}$ \\
\hline $\begin{array}{l}\text { Coutts and Sheikh } \\
(2002)\end{array}$ & 1987 to 1997 & South Africa & OLS & Gold index & No day-of-the-week effect \\
\hline Darrat et al. (2013) & 1973 to 2012 & South Africa & GARCH & Stock exchange data & $\begin{array}{l}\text { Negative Monday effect disappears } \\
\text { after } 2008\end{array}$ \\
\hline $\begin{array}{l}\text { Dicle and Levendis } \\
\text { (2014) }\end{array}$ & 2000 to 2007 & $\begin{array}{l}33 \text { countries on various } \\
\text { continents }\end{array}$ & GARCH & Stock exchange data & $\begin{array}{l}\text { Day-of-the-week effect for significant } \\
\text { number of stocks in almost all }\end{array}$ \\
\hline
\end{tabular}




\begin{tabular}{|c|c|c|c|c|c|}
\hline & & & & & $\begin{array}{l}\text { markets. Negative Monday effect in } \\
\text { South Africa. }\end{array}$ \\
\hline $\begin{array}{l}\text { Hsieh and Chen } \\
\text { (2012) }\end{array}$ & 2005 to 2011 & Taiwan & Stochastic dominance & $\begin{array}{l}\text { Taiwan Interbank Call Loan } \\
\text { Market }\end{array}$ & Monday effect \\
\hline Hui (2005) & 1998 to 2001 & $\begin{array}{l}\text { Hong Kong, Korea, Singapore, } \\
\text { Taiwan }\end{array}$ & ANOVA, Kruskall-Wallis & Stock exchange data & $\begin{array}{l}\text { No day-of-the-week effect, except } \\
\text { Singapore }\end{array}$ \\
\hline Kalidas et al. (2013) & 2004 to 2012 & $\begin{array}{l}\text { South Africa, Zambia, } \\
\text { Botswana, Nigeria, and } \\
\text { Morocco }\end{array}$ & $\begin{array}{l}\text { Skewness and kurtosis, } \\
\text { Kolmogorov-Smirnov }\end{array}$ & Stock exchange data & $\begin{array}{l}\text { No consistent pattern. No significant } \\
\text { effect in South Africa. }\end{array}$ \\
\hline Kothari et al. (2017) & 2005 to 2014 & India & $\begin{array}{l}\text { t-tests, ANOVA and } \\
\text { GARCH }\end{array}$ & Stock exchange data & Monday and Tuesday effects \\
\hline $\begin{array}{l}\text { Lakonishok and } \\
\text { Maberly (1990) }\end{array}$ & 1962 to 1986 & US & OLS & Stock exchange data & Increased selling on Mondays \\
\hline $\begin{array}{l}\text { Mbululu and Chipeta } \\
\text { (2012) }\end{array}$ & 1995 to 2011 & South Africa & $\begin{array}{l}\text { Skewness and kurtosis, } \\
\text { Kolmogorov-Smirnov }\end{array}$ & Stock exchange indices & $\begin{array}{l}\text { No day-of-the-week effect, except } \\
\text { basic materials }\end{array}$ \\
\hline $\begin{array}{l}\text { Mlambo and Biekpe } \\
\text { (2006) }\end{array}$ & $1997 / 1998$ to 2002 & Nine African Stock markets & $\begin{array}{l}\text { OLS, Kruskall-Wallis, } \\
\text { Chi-square }\end{array}$ & Stock exchange data & $\begin{array}{l}\text { Significant seasonal effects are found } \\
\text { on some, but not all indices }\end{array}$ \\
\hline Ndako (2013) & $\begin{array}{l}1990 \text { to } 2010 \\
\text { (split between '90-'95 and } \\
\text { '96-'10) }\end{array}$ & Nigeria and South Africa & EGARCH & Stock exchange data & $\begin{array}{l}\text { Nigeria - Monday and Tuesday effect } \\
\text { post-liberalisation } \\
\text { South Africa - Monday and Friday } \\
\text { effect pre-liberalisation, no effect } \\
\text { post- liberalisation }\end{array}$ \\
\hline $\begin{array}{l}\text { Nippani and } \\
\text { Pennathur (2004) }\end{array}$ & 1981 to 2000 & US & $\begin{array}{l}\text { t-tests, non-parametric } \\
\text { tests, binary regression }\end{array}$ & Commercial paper & Wednesday effect \\
\hline Plimsoll et al. (2013) & 2002 to 2012 & South Africa & GARCH & JSE Top 40 firms & No clear day-of-the-week effect \\
\hline Rowjee (2014a) & 1995 to 2012 & South Africa & $\begin{array}{l}\text { OLS, Kolmogorov- } \\
\text { Smirnov }\end{array}$ & Stock exchange indices & Dissipation of calendar effects \\
\hline $\begin{array}{l}\text { Smirlock and Starks } \\
\text { (1986) }\end{array}$ & 1963 to 1983 & US & OLS & Dow Jones Industrial Average & Differing patters over time \\
\hline Steeley (2001) & 1991 to 1998 & UK & Kruskal-Wallis & Stock exchange data & Monday effect \\
\hline $\begin{array}{l}\text { Ulussever et al. } \\
\text { (2011) }\end{array}$ & 2001 to 2009 & Saudi Arabia & GARCH & Stock exchange & Saturday effect \\
\hline
\end{tabular}

Source: Authors' own compilation 
The present study expand on the study by Mbululu and Chipeta (2012) to establish if changes to the time period and the statistical technique will change the outcome of the study, thereby confirming or disproving previous research on the day-of-the-week. The contribution is that the outcome of other day-of-the-week studies could be altered by means of extended time periods and different statistical techniques. The section that follows describes the research method to achieve the objectives of the study.

\section{Data, Variables, and Empirical Model}

We use daily closing share prices from eight industry indices of the Johannesburg Stock Exchange (JSE) for the period July 1995 to March 2016. Index data was chosen, as it acts as a proxy of the entire stock market, with the indices representing almost all the companies on the JSE, but at micro level to observe individual differences in the behaviour of different industries. The indices included in the study are J510 (basic materials), J520 (industrials), J530 (consumer goods), J540 (health care), J550 (consumer services), J560 (telecommunications), J580 (financials), and J590 (technology). J500 was excluded, since it consist of only one company and is thus at firm-level and not comparable with index data. There are a total of 4905 daily observations, excluding holidays and the days before or after a public holiday to eliminate the possibility of 'false weekends' where other days imitate a Monday or Friday due to a holiday inbetween. The data was obtained from IRESS, a reliable supplier of South African financial data. Details of the dates excluded from the sample are available in the Appendix as Table A.1.

We use the following regression model to examine the day-of-the-week effect in JSE indices.

$$
R_{\dagger}=\lambda_{0}+\sum_{j-1}^{5} \lambda_{j} D_{j \dagger}+\xi_{\dagger}
$$

where $R_{t}$ is the JSE indices return on day $t$, and $D_{j}$ represents day-of-the-week dummy variables for Monday, Tuesday, Wednesday, Thursday and Friday, respectively. Return series for the closing share prices of the JSE indices are not readily available and have to be calculated from closing share prices. 
Returns are calculated as

$$
{ }_{t}=\left(\ln P_{t}-\ln P_{t-1}\right) \times 100
$$

where, $P_{t}$ is most recent closing index value of one of the eight share indices; and $P_{t-1}$ is previous day's closing index value for one of the eight share indices.

The regression model assumes the existence of a constant variance, which may result in inefficient estimates, if there is a time varying variance. Hence, we include the changing variance into the estimation. Here, we assume that the error term of the return equation has a normal distribution with a zero mean and a constant variance. However, in many instances, financial time series exhibit periods of unusually high volatility, followed by periods of relative tranquillity. In such situations, the assumption of a constant variance is inappropriate. Engle (1982, 1995), Bollerslev (1986), Bollerslev and Ghysels (1996), amongst others, developed a class of models that address such concerns and also allow for modelling both the level (the first moment) and the variance (the second moment) of a process. To examine the effect of assuming a time varying variance, we re-estimate the equation [1] with the $\mathrm{GARCH}(p, q)$ type model with weekday dummies in the mean equation. The general description of this $\mathrm{GARCH}^{\mathrm{i}}$ model is as follows:

\section{Conditional mean equation}

$$
R_{t}=\lambda_{0}+\beta X_{t}+\xi_{t}
$$

where, $\mathrm{R}_{\mathrm{t}}$ represents stock returns; $\lambda_{0}$ is the coefficient of the model; and $\varepsilon_{\mathrm{t}} \sim$ iid $\left(0, \sigma_{t}{ }^{2}\right)$.

\section{Conditional variance equation}

$$
\boldsymbol{R}_{t}=\lambda_{\mathrm{o}}+\sum_{i-1}^{p} \lambda_{i} \varepsilon_{t-i}{ }^{2}+\sum_{j=1}^{q} \delta_{j} \sigma_{t-j}{ }^{2}+\xi_{t}
$$

where, $\lambda_{0}>0, \lambda_{i} \geq 0, \delta_{j} \geq 0$, and $\lambda_{i+} \delta_{j}<1$.

$\lambda_{i}(i=1,2, \ldots p)$ is the coefficients of the lagged squared residuals and $\delta_{j}(j=1,2, \ldots q)$ is the lagged conditional variance. 
In this model, the conditional variance depends upon the square of past values of process $\varepsilon_{\mathrm{t}}$ and lag of conditional variance $\sigma_{\mathrm{t}-1}^{2}$. The condition of non-negativity of parameter is also applied in this model.

\section{Empirical Results and Discussion}

Table 2 presents descriptive statistics for the returns for the entire time period, as well as the return for each day of the week. The average return for the entire study varies from -0.001 (J540) to 0.048 (J550). The average daily return is highest on a Monday and lowest on a Friday (see Table A.4 in the Appendix). However, in some cases, we observe an increase in the daily returns between Mondays and Tuesdays, leading to higher rates placed on JSE shares on Tuesdays. The most important result from this panel is the negative return on Fridays for all eight indices. As expected, this is the same as the results obtained by Mbululu and Chipeta (2012), who found that all mean returns were positive on Mondays and negative for Fridays.

We do not find any continuous increase or continuous decrease of daily returns in any of the eight indices (J510 to J590). The daily returns are negatively skewed and fat-tailed in few cases, while the kurtosis values are all positive.

Table 2: Descriptive Statistics (Index-wise)

\begin{tabular}{lrrrrrr}
\hline Indices & Mean & \multicolumn{1}{c}{ SD } & Minimum & Maximum & \multicolumn{1}{c}{ SK } & Observations \\
\hline J510 & 0.015 & 1.723 & -11.81 & 11.16 & -0.001 & 4904 \\
J520 & 0.039 & 1.235 & -13.62 & 7.687 & -0.507 & 4904 \\
J530 & 0.063 & 1.613 & -12.34 & 14.21 & 0.229 & 4904 \\
J540 & -0.001 & 3.53 & -228.5 & 10.54 & -0.561 & 4904 \\
J550 & 0.048 & 1.254 & -10.71 & 7.496 & -0.397 & 4904 \\
J560 & 0.04 & 2.071 & -18.69 & 19.65 & -0.061 & 4904 \\
J580 & 0.029 & 1.296 & -13.31 & 7.983 & -0.463 & 4904 \\
J590 & 0.043 & 1.925 & -20.8 & 15.11 & -0.618 & 4904 \\
\hline
\end{tabular}

Note 1: J510-J590 are the JSE stock indices.

Note 2: SD is standard deviation, and SK is skewness.

The implication of the descriptive statistics is that the data series is non-normally distributed"i We also find non-constancy of both mean variances across the days of the week which holds true for all these eight indices. However, these differences are not statically significant ${ }^{\mathrm{iii}}$ in most 
of the cases (see Table 3). The differences in mean returns between Monday and other days of the week are statistically significant in some of the cases, particularly for the indices J520, J540 and J550. Similarly, the differences in mean returns between Wednesday and other days of the week are statistically significant in some of the cases, particularly for the indices J520, J530, J540, and J550. Additionally, the differences in mean returns between Thursday and other days of the week are statistically significant in some of the cases, particularly for the indices J520, J530, J540, J550 and J580.

Table 3: The day-of-the-week Effect in Mean of South African stock Indices

\begin{tabular}{|c|c|c|c|c|c|c|c|}
\hline \multirow{2}{*}{ Indices } & \multirow{2}{*}{$\begin{array}{c}\text { Weekday } \\
\text { (J) }\end{array}$} & \multirow{2}{*}{$\begin{array}{c}\text { Weekday } \\
\text { (K) }\end{array}$} & \multirow{2}{*}{$\begin{array}{c}\text { MD } \\
(\mathrm{J}-\mathrm{K})\end{array}$} & \multirow{2}{*}{$\begin{array}{l}\text { Standard } \\
\text { error }\end{array}$} & \multirow{2}{*}{ P-value } & \multicolumn{2}{|c|}{ 95\% Confidence Interval } \\
\hline & & & & & & LB & UB \\
\hline \multirow[t]{10}{*}{$\mathrm{J} 510$} & Monday & Tuesday & 0.06 & 0.11 & 0.61 & -0.16 & 0.27 \\
\hline & & Wednesday & 0.08 & 0.09 & 0.43 & -0.12 & 0.27 \\
\hline & & Thursday & -0.02 & 0.10 & 0.84 & -0.21 & 0.17 \\
\hline & & Friday & 0.01 & 0.09 & 0.92 & -0.18 & 0.20 \\
\hline & Tuesday & Wednesday & 0.03 & 0.11 & 0.82 & -0.20 & 0.25 \\
\hline & & Thursday & -0.06 & 0.11 & 0.62 & -0.28 & 0.17 \\
\hline & & Friday & -0.01 & 0.11 & 0.96 & -0.23 & 0.22 \\
\hline & Wednesday & Thursday & -0.13 & 0.09 & 0.16 & -0.30 & 0.05 \\
\hline & & Friday & -0.07 & 0.10 & 0.47 & -0.27 & 0.13 \\
\hline & Thursday & Friday & 0.05 & 0.09 & 0.59 & -0.14 & 0.24 \\
\hline \multirow[t]{10}{*}{ J520 } & Monday & Tuesday & 0.06 & 0.07 & 0.37 & -0.07 & 0.19 \\
\hline & & Wednesday & -0.001 & 0.06 & 0.98 & -0.12 & 0.12 \\
\hline & & Thursday & -0.13 & 0.06 & $0.03^{* \star}$ & -0.25 & -0.01 \\
\hline & & Friday & 0.09 & 0.08 & 0.24 & -0.06 & 0.25 \\
\hline & Tuesday & Wednesday & -0.07 & 0.06 & 0.26 & -0.19 & 0.05 \\
\hline & & Thursday & -0.18 & 0.06 & $0.002^{\star \star \star}$ & -0.29 & -0.07 \\
\hline & & Friday & 0.06 & 0.08 & 0.47 & -0.09 & 0.20 \\
\hline & Wednesday & Thursday & -0.13 & 0.05 & $0.02^{* *}$ & -0.24 & -0.02 \\
\hline & & Friday & 0.09 & 0.07 & 0.2 & -0.05 & 0.24 \\
\hline & Thursday & Friday & 0.22 & 0.07 & $0.002^{* * *}$ & 0.08 & 0.35 \\
\hline \multirow[t]{9}{*}{ J530 } & Monday & Tuesday & -0.004 & 0.13 & 0.98 & -0.27 & 0.26 \\
\hline & & Wednesday & -0.06 & 0.13 & 0.65 & -0.31 & 0.20 \\
\hline & & Thursday & -0.05 & 0.13 & 0.71 & -0.31 & 0.21 \\
\hline & & Friday & 0.15 & 0.14 & 0.28 & -0.12 & 0.42 \\
\hline & Tuesday & Wednesday & -0.07 & 0.07 & 0.35 & -0.20 & 0.07 \\
\hline & & Thursday & -0.04 & 0.08 & 0.59 & -0.20 & 0.11 \\
\hline & & Friday & 0.16 & 0.09 & 0.07 & -0.014 & 0.34 \\
\hline & Wednesday & Thursday & -0.014 & 0.06 & 0.82 & -0.13 & 0.10 \\
\hline & & Friday & 0.19 & 0.08 & 0.01 & 0.05 & 0.35 \\
\hline
\end{tabular}




\begin{tabular}{|c|c|c|c|c|c|c|c|}
\hline & Thursday & Friday & 0.2 & 0.08 & 0.02 & 0.04 & 0.36 \\
\hline \multirow[t]{10}{*}{$\mathrm{J} 540$} & Monday & Tuesday & -0.03 & 0.07 & 0.68 & -0.17 & 0.11 \\
\hline & & Wednesday & -0.07 & 0.07 & 0.31 & -0.21 & 0.07 \\
\hline & & Thursday & -0.18 & 0.07 & $0.01^{* * *}$ & -0.31 & -0.05 \\
\hline & & Friday & 0.06 & 0.08 & 0.46 & -0.09 & 0.22 \\
\hline & Tuesday & Wednesday & -0.04 & 0.07 & 0.62 & -0.17 & 0.10 \\
\hline & & Thursday & -0.15 & 0.07 & $0.03^{\star *}$ & -0.28 & -0.01 \\
\hline & & Friday & 0.11 & 0.08 & 0.19 & -0.05 & 0.28 \\
\hline & Wednesday & Thursday & -0.12 & 0.07 & $0.08^{*}$ & -0.25 & 0.02 \\
\hline & & Friday & 0.13 & 0.08 & 0.13 & -0.04 & 0.29 \\
\hline & Thursday & Friday & 0.24 & 0.08 & $0.003^{* * *}$ & 0.08 & 0.39 \\
\hline \multirow[t]{10}{*}{$\mathrm{J} 550$} & Monday & Tuesday & -0.09 & 0.06 & 0.13 & -0.22 & 0.03 \\
\hline & & Wednesday & -0.14 & 0.08 & $0.07^{*}$ & -0.30 & 0.01 \\
\hline & & Thursday & -0.21 & 0.05 & $0.00^{* * *}$ & -0.31 & -0.10 \\
\hline & & Friday & 0.004 & 0.07 & 0.95 & -0.13 & 0.13 \\
\hline & Tuesday & Wednesday & -0.07 & 0.08 & 0.42 & -0.23 & 0.10 \\
\hline & & Thursday & -0.11 & 0.06 & $0.06^{*}$ & -0.23 & 0.01 \\
\hline & & Friday & 0.11 & 0.07 & 0.13 & -0.03 & 0.24 \\
\hline & Wednesday & Thursday & -0.07 & 0.07 & 0.37 & -0.21 & 0.08 \\
\hline & & Friday & 0.15 & 0.08 & $0.07^{*}$ & -0.01 & 0.31 \\
\hline & Thursday & Friday & 0.21 & 0.06 & $0.00^{* * *}$ & 0.09 & 0.33 \\
\hline \multirow[t]{10}{*}{$\mathrm{J} 560$} & Monday & Tuesday & 0.09 & 0.13 & 0.48 & -0.17 & 0.35 \\
\hline & & Wednesday & 0.07 & 0.13 & 0.63 & -0.19 & 0.33 \\
\hline & & Thursday & -0.13 & 0.13 & 0.30 & -0.38 & 0.12 \\
\hline & & Friday & 0.13 & 0.14 & 0.37 & -0.15 & 0.41 \\
\hline & Tuesday & Wednesday & -0.03 & 0.12 & 0.79 & -0.27 & 0.21 \\
\hline & & Thursday & -0.21 & 0.12 & $0.08^{*}$ & -0.44 & 0.03 \\
\hline & & Friday & 0.11 & 0.14 & 0.43 & -0.17 & 0.39 \\
\hline & Wednesday & Thursday & -0.18 & 0.12 & 0.12 & -0.41 & 0.05 \\
\hline & & Friday & 0.13 & 0.14 & 0.36 & -0.14 & 0.40 \\
\hline & Thursday & Friday & & & & & \\
\hline \multirow[t]{10}{*}{ J580 } & Monday & Tuesday & 0.03 & 0.07 & 0.73 & -0.11 & 0.17 \\
\hline & & Wednesday & -0.05 & 0.06 & 0.39 & -0.17 & 0.07 \\
\hline & & Thursday & -0.1 & 0.06 & $0.08^{*}$ & -0.22 & 0.01 \\
\hline & & Friday & 0.01 & 0.08 & 0.89 & -0.15 & 0.17 \\
\hline & Tuesday & Wednesday & -0.09 & 0.07 & 0.19 & -0.23 & 0.04 \\
\hline & & Thursday & -0.15 & 0.07 & $0.03^{* *}$ & -0.29 & -0.01 \\
\hline & & Friday & 0.01 & 0.09 & 0.92 & -0.16 & 0.18 \\
\hline & Wednesday & Thursday & -0.06 & 0.05 & 0.27 & -0.17 & 0.05 \\
\hline & & Friday & 0.07 & 0.07 & 0.37 & -0.08 & 0.22 \\
\hline & Thursday & Friday & 0.14 & 0.08 & $0.08^{*}$ & -0.02 & 0.29 \\
\hline
\end{tabular}




\begin{tabular}{|c|c|c|c|c|c|c|c|}
\hline \multirow[t]{10}{*}{ J590 } & \multirow[t]{4}{*}{ Monday } & Tuesday & -0.08 & 0.15 & 0.60 & -0.39 & 0.22 \\
\hline & & Wednesday & -0.1 & 0.14 & 0.50 & -0.38 & 0.19 \\
\hline & & Thursday & -0.14 & 0.15 & 0.34 & -0.43 & 0.16 \\
\hline & & Friday & -0.1 & 0.19 & 0.61 & -0.47 & 0.27 \\
\hline & \multirow[t]{3}{*}{ Tuesday } & Wednesday & -0.03 & 0.07 & 0.65 & -0.18 & 0.11 \\
\hline & & Thursday & -0.07 & 0.08 & 0.40 & -0.22 & 0.09 \\
\hline & & Friday & 0.0004 & 0.14 & 0.99 & -0.28 & 0.28 \\
\hline & \multirow[t]{2}{*}{ Wednesday } & Thursday & -0.04 & 0.06 & 0.50 & -0.15 & 0.07 \\
\hline & & Friday & 0.01 & 0.13 & 0.93 & -0.24 & 0.27 \\
\hline & Thursday & Friday & 0.07 & 0.13 & 0.62 & -0.19 & 0.32 \\
\hline
\end{tabular}

Note 1: J510-J590 are the JSE stock indices.

Note 2: ${ }^{*},{ }^{* *}$, and ${ }^{* * *}$ are statistical significance at $1 \%, 5 \%$ and $10 \%$ levels.

We use the Wald statistic to test the null hypothesis that all coefficients of the day of the week are equal. The coefficient estimates and the Wald test statistics are reported in Table 4. The estimated coefficients represent the mean returns and the binary variables Monday, Tuesday, Wednesday, Thursday, and Friday take a value of one if the return shows a day-of-the-week effect, zero otherwise. The results of this OLS estimation show that Fridays has the lowest return, while Mondays has the highest return. That means the daily returns on Mondays are affected by the other days. Monday is the only day where we observe a positive effect for all indices. For other days, we observe both positive and negative effects, which vary from index to index. Most importantly, we observe a positive effect for J540 on all days.

Table 4: Day-of-the-week Effects in SA stock Indices

\begin{tabular}{|c|c|c|c|c|c|c|}
\hline Indices & Monday & Tuesday & Wednesday & Thursday & Friday & F-test \\
\hline $\mathrm{J} 510$ & $0.070[0.20]$ & $-0.017[0.76]$ & $-0.013[0.82]$ & $0.064[0.24]$ & $-0.031[0.57]$ & 0.69 [0.63] \\
\hline J520 & $0.059[0.14]$ & $0.078[0.05]$ & $0.039[0.32]$ & 0.05 [0.22] & $-0.030[0.48]$ & $1.80[0.10]$ \\
\hline J530 & $0.134[0.01]$ & $0.069[0.18]$ & $0.041[0.41]$ & $0.096[0.06]$ & $-0.026[0.61]$ & $2.60[0.02]$ \\
\hline $\mathrm{J} 540$ & $0.091[0.43]$ & $0.080[0.48]$ & $0.049[0.66]$ & $-0.200[0.07]$ & $-0.020[0.84]$ & $0.91[0.48]$ \\
\hline J550 & $0.051[0.20]$ & $0.090[0.02]$ & $0.053[0.18]$ & $0.044[0.26]$ & $-0.007[0.86]$ & $2.07[0.07]$ \\
\hline J560 & $0.116[0.08]$ & $0.107[0.10]$ & $-0.05[0.44]$ & $0.060[0.37]$ & $-0.028[0.67]$ & $1.45[0.20]$ \\
\hline J580 & $0.035[0.40]$ & $0.079[0.06]$ & $0.058[0.16]$ & $0.024[0.56]$ & $-0.054[0.19]$ & $1.68[0.14]$ \\
\hline J590 & $0.129[0.03]$ & $0.073[0.23]$ & $0.001[0.99]$ & $0.016[0.80]$ & $-0.004[0.94]$ & 1.19 [0.31] \\
\hline
\end{tabular}

Note: parentheses indicate the probability level of significance.

We observe that the coefficients of these estimates are statistically significant in few cases only.

These cases are J520 (on Tuesday), J530 (on Thursday), J540 (on Thursday), J550 (on Tuesday), J560 (on Monday), and J590 (on Monday). Most importantly, in the case of J530 and 
J550, the overall impact, judged through the F-statistic, is also statistically significant. This is one of the most unique findings in this panel. The sector-wise summary of these day-of-theweek effects are available as Table A.3 in the Appendix.

Recent works to examine conditional volatility models are motivated by the existence of stylised facts and salient features of volatility. To analyse volatility characteristics, we check the ARCH effect in the time series by using LM statistics after obtaining the autoregressive model residuals. We use the AR residuals of the JSE stock indices regressed on a constant term and past lagged residuals values. These results are not reported here due to space constraints.

To investigate the effect of assuming a time varying variance, we estimate equation (2) with a GARCH (p, q) that fits the data series on the basis of AIC, SIC and HQIC criteria. Empirical studies estimating GARCH-type models typically assume a normal error distribution. We choose a $\operatorname{GARCH}(1,1)$ model to examine the effect of time varying variance.

In Table 5, the GARCH ${ }^{\text {iv }}$ model is employed to explore the mean and volatility spill-over effect in all the indices, $\mathrm{J} 510$ to $\mathrm{J} 590^{\vee}$. These estimated equations analyse the mean and volatility spillover effect from J510 to J590. To trace out the mean spill-over effect, we introduced the return series of these indices in the conditional mean equation. For exploring the volatility spill-over effect from $\mathrm{J} 510$ to $\mathrm{J} 590$, we introduced the squared return series of these indices into the conditional variance equation. 
Table 5: Mean Equation and Conditional Variance Equation of JSE Indices

\begin{tabular}{|c|c|c|c|c|c|c|c|c|}
\hline Variables/coefficients & J510 & J520 & $\mathrm{J} 530$ & $\mathrm{~J} 540$ & J550 & J560 & $\mathrm{J} 580$ & J590 \\
\hline \multicolumn{9}{|l|}{ Part A: Mean Equation } \\
\hline Monday & $0.112^{*}$ & $0.079^{*}$ & $0.180^{*}$ & $0.169^{*}$ & $0.098^{*}$ & $0.106^{*}$ & $0.052^{*}$ & $0.141^{*}$ \\
\hline Tuesday & 0.006 & $0.094^{*}$ & 0.029 & $0.106^{*}$ & $0.113^{*}$ & $0.96^{*}$ & $0.080^{*}$ & $0.107^{*}$ \\
\hline Wednesday & -0.014 & $0.068^{*}$ & $0.800^{*}$ & $0.600^{*}$ & $0.119^{*}$ & $0.047^{*}$ & $0.070^{*}$ & $0.082^{*}$ \\
\hline Thursday & 0.043 & $0.103^{*}$ & $0.123^{*}$ & $-0.014^{*}$ & $0.106^{*}$ & $0.127^{*}$ & $0.119^{*}$ & $0.099^{*}$ \\
\hline Friday & -0.022 & $0.071^{*}$ & 0.0395 & $0.085^{\star}$ & $0.048^{*}$ & $0.047^{*}$ & $0.025^{*}$ & $0.128^{*}$ \\
\hline \multicolumn{9}{|l|}{ Part B: Variance Equation } \\
\hline Constant & $0.017^{*}$ & $0.036^{*}$ & $0.031^{*}$ & $0.755^{\star}$ & $0.018^{*}$ & $0.058^{*}$ & $0.025^{*}$ & $0.037^{*}$ \\
\hline Coefficient of ARCH effect & $0.069^{*}$ & $0.115^{\star}$ & $0.09^{*}$ & $0.98^{*}$ & $0.107^{*}$ & $0.094^{*}$ & $0.122^{*}$ & $0.118^{*}$ \\
\hline Coefficient of GARCH effect & $0.929^{*}$ & $0.865^{\star}$ & $0.901^{*}$ & $0.040^{*}$ & $0.887^{*}$ & $0.896^{*}$ & $0.868^{*}$ & $0.884^{*}$ \\
\hline \multicolumn{9}{|l|}{ Part C: Model Diagnostics } \\
\hline Log Likelihood & -8926.5 & -7398.8 & -8643.4 & -9814.4 & -7413.5 & -9911.8 & -7370.5 & -9170.4 \\
\hline DW & 1.843 & 1.889 & 1.939 & 1.967 & 1.836 & 1.9 & 1.793 & 1.794 \\
\hline $\mathrm{AIC}$ & 3.644 & 3.021 & 3.528 & 4.006 & 3.027 & 4.056 & 3.009 & 3.743 \\
\hline SIC & 3.654 & 3.031 & 3.539 & 4.016 & 3.037 & 4.056 & 3.019 & 3.754 \\
\hline HQIC & 3.647 & 3.024 & 3.532 & 4.009 & 3.03 & 4.049 & 3.013 & 3.747 \\
\hline
\end{tabular}

Note 1: J510-J590 are the JSE stock indices.

Note 2: DW is Durbin-Watson 'd' statistics, AIC is Akaike information criterion, SIC is Schwarz information criterion, and HQIC is HannanQuinn information criterion.

Note 3 : $^{*}$ is statistical significance at $1 \%$ level.

The results explain that the parameter of both mean equation and variance equation are statistically significant for all eight indices. It means that there exist mean and volatility spill-over effects. The results are well-supported in all the model diagnostics.

We found some meaningful observations:

Firstly, our evidence supports the presence of the day-of-the-week effect with Monday having the highest average return and Friday having the lowest. While comparing with Tuesday, the average return on Monday is slightly lower in some indices while that of Friday is lower on average for all indices. The average return tends to decline daily from Monday through to Friday.

Secondly, index-wise, we observe the day-of the-week effect for most of the days and for all indices except J510, which shows only a Monday effect. Additionally, we find some day-of-theweek effect for all days for J520 and J550 (see Table 4). 
Thirdly, the reported day-of-the-week effect is sensitive to assumptions about the underlying distribution. Specifically, assuming a normal distribution, the average daily return for Monday is significant at the $1 \%$ level for all indices. However, this finding is not supported under other distributions such as Student's t, GED, and DED.

Fourthly, the results of the diagnostic tests show that all the GARCH models are correctly specified. The Ljung-Box statistics of up to 50 lags could not reject the null hypothesis of no autocorrelation. Lagrange multiplier tests are also significant, indicating that the four GARCH processes are successful at modelling the conditional volatility. The Jarque-Bera (JB) test for normality rejects the null hypothesis that standardized residuals are normally distributed. The results are also consistent with other diagnostics indicators like Durbin-Watson (DW) ' $d$ ' statistics, log-likelihood ratio, AIC, SIC and HQIC statistics. This is an indication that the GARCH model is an appropriate technique for the identification of possible day-of-the-week effects.

Fifthly, for all eight cases, the sum of the parameters estimated by the variance equation is close to one. A sum of $\lambda 1$ and $\delta 1$ near one indicates a covariance stationary model with a high degree of persistence and a long memory in the conditional variance. The sum of $\lambda 1$ and $\delta 1$ is also an estimation of the rate at which the response function decays on a daily basis. Since the rates are quite high, the response functions to shocks are likely to be slow in coming to an end. This indicates that sudden volatility takes some time to be absorbed into the market.

Sixthly, the coefficients of ARCH term $(\lambda)$ and the GARCH term $(\delta)$ are found different from zero for all the eight indices, indicating that the lagged values of the residuals and the lagged values of the conditional variance are able to capture future volatility.

Over and above these findings, some supplementary results, though not exhaustive, deserve reference. Firstly, to check the robustness of our results, we obtained bonus estimates by including all holidays in the OLS estimation process. The results of these estimations are congruent with our original estimation (excluding holiday data) and hence support our findings. Secondly, we engaged different volatility models such as EGARCH to provide more information about the conditional volatility. The findings justify the presence of volatility asymmetry in a few cases, indicating that a negative shock has a greater impact on volatility than positive shocks of 
the same magnitude. Thirdly, we deployed a unit root test ${ }^{\mathrm{vi}}$ to observe the stationarity of these indices and the test statistics strongly rejects the unit root hypothesis of a lack of stationarity for all eight indexes.

The outcomes of OLS estimations, volatility estimations and unit root test statistics are not reported here due to space constraints, but are available upon request.

\section{Policy Implications and Concluding Remarks}

The study investigates the day-of-the-week effects of Johannesburg Stock Exchange (JSE) indices for the period July 1995 to March 2016. We examine eight JSE indices, covering J510 (basic materials), J520 (industrials), J530 (consumer goods), J540 (health care), J550 (consumer services), J560 (telecommunications), J580 (financials), and J590 (technology). Our results indicate that the most significant and consistent pattern are on Mondays and Tuesdays, where the mean returns are all positive, and Fridays, where the mean returns are all negative.

Mbululu and Chipeta (2012) used skewness and kurtosis, the Kolmogorov-Smirnov test on higher statistical moments, as well as the Q-index, to test for the presence of a day-of-the-week effect. They found that there is no evidence of a day-of-the-week effect for eight of the nine sectors of the JSE, and a Monday effect for the Basic Materials sector only. Our results, using the same type of data but with an additional number of years and different statistical techniques, show that the day-of-the-week effect is present, but not uniform across all eight indices. Our results indicate that the most significant and consistent pattern are on Mondays, where all coefficients are positive, and Fridays, where all coefficients are negative. These results are similar to the findings of Alagidede (2008), Darrat et al. (2013) and Ndako (2013), who all used similar statistical techniques to this study and South African data.

Moreover, the day-of-the-week effect in both mean and conditional volatility is sensitive to the choice of error distribution. In all the cases, the conditional volatility varies with the days of the week. Although most of the dummy variables have a positive sign, the conditional volatility 
varies from index to index. The results indicate that a day-of-the-week effect is mostly a function of the statistical technique applied. Our findings cast thus doubt on the various arguments put forward in the literature to explain the day-of-the-week effect and open a new avenue of research to identify this market anomaly. This is important to both market participants and academics, as the correct statistical technique and the optimal time period should provide consistent results every time such a study is conducted.

This study adds to the existing literature on the day-of-the-week effect of JSE indices, where several unique patterns or no pattern at all have been noted by prior studies. Future research could investigate the presence of the day-of-the-week, using the same statistical techniques and the same dataset used in this study at either stock exchange-level (i.e. macro-level), or at firm-level, as has been suggested by Mbululu and Chipeta (2012). The study can also be replicated to other stock markets to establish whether, if the similar data, time periods and statistical techniques are consistently applies, the day-of-the-week-effect differs between countries.

\section{References}

Abraham, A., and D. L. Ikenberry, 1994. The individual investor and the weekend effect. Journal of Financial and Quantitative Analysis, 29(02), 263-277.

Aggarwal, R., and P. Rivoli, 1989. Seasonal and day-of-the-week effects in four emerging stock markets. Financial review, 24(4), 541-550.

Akbalik, M., and N. Ozkan, 2017. Day of the Week Effect in the Stock Markets of Fragile Five Countries After 2008 Global Financial Crisis. Berlin: Springer.

Al-Loughani, N. E., K. M. Al-Saad, and M. M. Ali, 2005. The holiday effect and stock return in the Kuwait Stock Exchange. Global Competitiveness, 13(1), 81-91.

Alagidede, P., 2008. Day of the week seasonality in African stock markets. Applied Financial Economics Letters, 4(2), 115-120.

Berument, M., and N. Dogan, 2012. Stock market return and volatility: day-of-the-week effect. Journal of Economics \& Finance, 36(2), 282-302. doi:10.1007/s12197-009-9118-y 
Bhana, N., 1985. The Monday effect on the Johannesburg Stock Exchange. South African Journal of Business Management, 16(1), 7-11.

Bollerslev, T., 1986. Generalized autoregressive conditional heteroskedasticity. Journal of econometrics, 31(3), 307-327.

Bollerslev, T., and E. Ghysels, 1996. Periodic autoregressive conditional heteroscedasticity. Journal of Business \& Economic Statistics, 14(2), 139-151.

Brockman, P., and D. Michayluk, 1998. Individual versus institutional investors and the weekend effect. Journal of Economics and Finance, 22(1), 71-85.

Brusa, J., and P. Liu, 2004. The day-of-the-week and the week-of-the-month effects: An analysis of investors' trading activities. Review of Quantitative Finance and Accounting, 23(1), 19-30.

Brusa, J., P. Liu, and C. Schulman, 2003. The weekend effect, 'reverse' weekend effect, and firm size. Journal of Business Finance \& Accounting, 27(5-6), 555-574.

Chang, E. C., J. M. Pinegar, and R. Ravichandran, 1993. International evidence on the robustness of the day-of-the-week effect. Journal of Financial and Quantitative Analysis, 28(04), 497-513.

Chatterjee, S., 2017. Day of the Week Effect in biotechnology stocks: An Application of the GARCH processes. arXiv preprint arXiv:1701.07175.

Choudhary, K., and S. Choudhary, 2008. Day-of-the-week effect: further empirical evidence. Asia Pacific Business Review, 4(3), 67-74.

Chukwuogor, C., 2007. An econometric analysis of African Stock Market: annual returns analysis, day-of-the-week effect and volatility of returns. African Journal of Accounting, Economics, Finance and Banking Research, 1(1), 26.

Coutts, J. A., and M. A. Sheikh, 2002. The anomalies that aren't there: the weekend, January and pre-holiday effects on the all gold index on the Johannesburg Stock Exchange 1987-1997. Applied Financial Economics, 12(12), 863-871.

Darrat, A. F., B. Li, and R. Chung, 2013. Seasonal anomalies: A closer look at the Johannesburg Stock Exchange. Contemporary Management Research, 9(2), 155.

Dicle, M., and J. Levendis, 2014. The day-of-the-week effect revisited: international evidence. Journal of Economics \& Finance, 38(3), 407-437. doi:10.1007/s12197-011-9223-6 
Engle, R. F., 1982. Autoregressive conditional heteroscedasticity with estimates of the variance of United Kingdom inflation. Econometrica: Journal of the Econometric Society, 9871007.

Engle, R. F., 1995. ARCH: selected readings. Oxford: Oxford University Press.

Fields, M. J., 1931. Stock prices: a problem in verification. Journal of Business, 4, 415-418.

Hamid, K., M. Suleman, S. Ali Shah, and S. Akkash Imdad, 2010. Testing the weak form of efficient market hypothesis: Empirical evidence from Asia-Pacific markets. International Research Journal of Finance and Economics, 2010(58).

Hsieh, C. S., and C. T. Chen, 2012. Using stochastic dominance criterion to examine the dayof-the-week effect. Applied Financial Economics, 22(14), 1207-1213. doi:10.1080/09603107.2011.646061

Hui, T.-K., 2005. Day-of-the-week effects in US and Asia-Pacific stock markets during the Asian financial crisis: a non-parametric approach. Omega, 33(3), 277-282.

Jefferis, K., and G. Smith, 2005. The changing efficiency of African stock markets. South African Journal of Economics, 73(1), 54-67.

Kalidas, S., D. Mbululu, and C. Chipeta, 2013. Changing patterns in the day-of-the-week effects in African stock markets. The International Business \& Economics Research Journal (Online), 12(10), 1157.

Kothari, H. C., P. Singh, and S. Patra, 2017. Existence of Day-of-the-Week Effect in Returns of Some Selected Indices of the Indian Stock Market. Indian Journal of Research in Capital Markets, 4(1), 26-41.

Lakonishok, J., and E. Maberly, 1990. The weekend effect: Trading patterns of individual and institutional investors. The Journal of Finance, 45(1), 231-243.

Latif, M., S. Arshad, M. Fatima, and S. Farooq, 2011. Market efficiency, market anomalies, causes, evidences, and some behavioral aspects of market anomalies. Research journal of finance and accounting, 2(9), 1-13.

Malkiel, B. G., 2003. The efficient market hypothesis and its critics. The Journal of Economic Perspectives, 17(1), 59-82.

Mbululu, D., and C. Chipeta, 2012. Day-of-the-week effect: Evidence from the nine economic sectors of the JSE. Investment Analysts Journal, 2012(75), 55-65. 
Miller, E. M., 1988. Why a weekend effect. The Journal of Portfolio Management, 14(4), 43-48.

Mlambo, C., and N. Biekpe, 2006. Seasonal effects: Evidence from emerging African stock markets. South African Journal of Business Management, 37(3), 41-52.

Ndako, U. B., 2013. The day of the week effect on stock market returns and volatility: Evidence from Nigeria and South Africa. Munich Personal RePEc Archive.

Nippani, S., and A. K. Pennathur, 2004. Day-of-the-week effects in commercial paper yield rates. The Quarterly Review of Economics and Finance, 44(4), 508-520.

Pettengill, G. N., 2003. A survey of the Monday effect literature. Quarterly Journal of Business and Economics, 42(3/4), 3-27.

Plimsoll, J., B. Saban, A. Spheris, and K. Rajaratnam, 2013. The day of the week effect: An analysis of the Johannesburg Stock Exchange Top 40 firms. The International Business \& Economics Research Journal (Online), 12(3), 319.

Rowjee, B. 2014a. Calender effects on the nine economic sectors of the Johannesburg stock exchange. (Master of Commerce (Finance)), University of the Witwatersrand.

Rowjee, B. 2014b. Calender effects on the nine economic sectors of the Johannesburg Stock Exchange. (Unpublished doctoral thesis), University of the Witwatersrand, Johannesburg.

Smirlock, M., and L. Starks, 1986. Day-of-the-week and intraday effects in stock returns. Journal of Financial Economics, 17(1), 197-210. doi:http://dx.doi.org/10.1016/0304$405 \times(86) 90011-5$

Steeley, J. M., 2001. A note on information seasonality and the disappearance of the weekend effect in the UK stock market. Journal of Banking \& Finance, 25.

Ulussever, T., I. G. Yumusak, and M. Kar, 2011. The Day-of-the-Week Effect in the Saudi Stock Exchange: A Non-Linear Garch Analysis. Journal of Economic \& Social Studies (JECOSS), 1(1), 9-23. 


\section{Appendix}

Table A.1: South African Public Holidays That Were Excluded from the Data

\begin{tabular}{|l|c|}
\hline \multicolumn{1}{|c|}{ Holidays } & Dates \\
\hline New Year's Day & 1 January \\
\hline Human Rights Day & 21 March \\
\hline Good Friday & 3 April \\
\hline Family Day & 27 April \\
\hline Freedom Day & 1 May \\
\hline Worker's Day & 16 June \\
\hline Youth Day & 9 August \\
\hline National Women's Day & 24 September \\
\hline Heritage Day & 16 December \\
\hline Day of Reconciliation & 25 December \\
\hline Christmas Day & 26 December \\
\hline Day of Goodwill & \\
\hline
\end{tabular}


Table A.2: Easter Holidays

\begin{tabular}{|c|c|c|c|c|c|}
\hline Year & Day deleted & Good Friday & $\begin{array}{l}\text { Easter } \\
\text { Sunday }\end{array}$ & Family Day & Day deleted \\
\hline 1995 & 13 April & 14 April & 16 April & 17 April & 18 April \\
\hline 1996 & 4 April & 5 April & 7 April & 8 April & 9 April \\
\hline 1997 & 27 March & 28 March & 30 March & 31 March & 1 April \\
\hline 1998 & 9 April & 10 April & 12 April & 13 April & 14 April \\
\hline 1999 & 1 April & 2 April & 4 April & 5 April & 6 April \\
\hline 2000 & 20 April & 21 April & 23 April & 24 April & 25 April \\
\hline 2001 & 12 April & 13 April & 15 April & 16 April & 17 April \\
\hline 2002 & 28 March & 29 March & 31 March & 1 April & 2 April \\
\hline 2003 & 17 April & 18 April & 20 April & 21 April & 22 April \\
\hline 2004 & 8 April & 9 April & 11 April & 12 April & 13 April \\
\hline 2005 & 24 March & 25 March & 27 March & 28 March & 29 March \\
\hline 2006 & 13 April & 14 April & 16 April & 17 April & 18 April \\
\hline 2007 & 5 April & 6 April & 8 April & 9 April & 10 April \\
\hline 2008 & 20 March & 21 March & 23 March & 24 March & 25 March \\
\hline 2009 & 9 April & 10 April & 12 April & 13 April & 14 April \\
\hline 2010 & 1 April & 2 April & 4 April & 5 April & 6 April \\
\hline 2011 & 21 April & 22 April & 24 April & 25 April & 26 April \\
\hline 2012 & 5 April & 6 April & 8 April & 9 April & 10 April \\
\hline 2013 & 28 March & 29 March & 31 March & 1 April & 2 April \\
\hline 2014 & 17 April & 18 April & 20 April & 21 April & 22 April \\
\hline 2015 & 2 April & 3 April & 5 April & 6 April & 7 April \\
\hline 2016 & 24 March & 25 March & 27 March & 28 March & 29 March \\
\hline
\end{tabular}

Table A.3. Summary of Day-of-the-week Effects

\begin{tabular}{lcccccc}
\hline Sectors & Monday & Tuesday & Wednesday & Thursday & Friday & Overall \\
\hline Basic materials & $\mathrm{P}(\mathrm{NS})$ & $\mathrm{N}(\mathrm{NS})$ & $\mathrm{N}(\mathrm{NS})$ & $\mathrm{P}(\mathrm{NS})$ & $\mathrm{N}(\mathrm{NS})$ & $\mathrm{NS}$ \\
Industrials & $\mathrm{P}(\mathrm{NS})$ & $\mathrm{P}(\mathrm{S})$ & $\mathrm{P}(\mathrm{NS})$ & $\mathrm{P}(\mathrm{NS})$ & $\mathrm{N}(\mathrm{NS})$ & $\mathrm{S}$ \\
Consumer goods & $\mathrm{P}(\mathrm{S})$ & $\mathrm{P}(\mathrm{NS})$ & $\mathrm{P}(\mathrm{NS})$ & $\mathrm{P}(\mathrm{S})$ & $\mathrm{N}(\mathrm{NS})$ & $\mathrm{S}$ \\
Health care & $\mathrm{P}(\mathrm{NS})$ & $\mathrm{P}(\mathrm{NS})$ & $\mathrm{P}(\mathrm{NS})$ & $\mathrm{N}(\mathrm{NS})$ & $\mathrm{N}(\mathrm{NS})$ & $\mathrm{NS}$ \\
Consumer services & $\mathrm{P}(\mathrm{NS})$ & $\mathrm{N}(\mathrm{NS})$ & $\mathrm{N}(\mathrm{NS})$ & $\mathrm{P}(\mathrm{NS})$ & $\mathrm{N}(\mathrm{NS})$ & $\mathrm{S}$ \\
Telecommunications & $\mathrm{P}(\mathrm{S})$ & $\mathrm{P}(\mathrm{S})$ & $\mathrm{N}(\mathrm{NS})$ & $\mathrm{P}(\mathrm{NS})$ & $\mathrm{N}(\mathrm{NS})$ & $\mathrm{NS}$ \\
Financials & $\mathrm{P}(\mathrm{NS})$ & $\mathrm{P}(\mathrm{S})$ & $\mathrm{P}(\mathrm{NS})$ & $\mathrm{P}(\mathrm{NS})$ & $\mathrm{N}(\mathrm{NS})$ & $\mathrm{NS}$ \\
Technology & $\mathrm{P}(\mathrm{S})$ & $\mathrm{P}(\mathrm{NS})$ & $\mathrm{P}(\mathrm{NS})$ & $\mathrm{P}(\mathrm{NS})$ & $\mathrm{N}(\mathrm{NS})$ & $\mathrm{NS}$ \\
\hline
\end{tabular}

Note 1: $\mathrm{P}$ is positive effect, $\mathrm{N}$ is negative effect, NS is statistically not significant, and $\mathrm{S}$ is statistically significant.

Note 2: Overall impact is judged through the significance of F-statistics. 


\footnotetext{
'The model assumes weights on past squared residuals to decline geometrically at a rate to be

ii It is also verified by deploying the Jarque-Bera (JB) test.

iii It has been tested by a pair-wise mean test.

iv The experiment is also done for DJR-GARCH, PGARCH, GARCH-M, TGARCH, and FIEGARCH. However, we find the best approximation for $\operatorname{GARCH}(1,1)$.

$v$ The GARCH $(1,1)$ model is estimated for the normal distribution, Student's $t, G E D$, and DED. But the final results are reported for the normal distribution only. This is as per the best approximation on the basis of the usable data.

vi It is the use of the Augmented Dickey Fuller Test.
} 